\title{
INCREASING LEARNING ABOUT HALAL CERTIFICATION PROCESS THROUGH KNOWLEDGE MANAGEMENT SYSTEM
}

\author{
Suci Ratnawati, Yuni Sugiarti, Nia Kumaladewi
}

\author{
Information Systems Department \\ Faculty of Science and Technology \\ Syarif Hidayatullah State Islamic University Jakarta, Indonesia \\ Email: suci.ratnawati@uinjkt.ac.id, yuni.sugiarti@uinjkt.ac.id, \\ nia.kumaladewi@uinjkt.ac.id
}

\begin{abstract}
Knowledge management is needed to increase the utilization of knowledge in an organization. The higher the level of information needs by all stakeholders in an organizatio then the Knowledge Management Systems(KMS) will be a necessity for organization. KMS of Halal Food Certification as e-learning media will be increase knowledge about how to certified halal food product. From Knowledge Management System, food producer can learn how to certified their product. The main objective of this research is to study the process of knowledge management system at $\angle P P O M$ MUI. . The results of the study indicate that knowledge management system in LPPOM MUI, especially knowledge sharing between halal food producers, community and LPPOM MUI, needs to be improved. So that it can increase the benefits of knowledge owned by the community, food producers, and $\angle P P O M$ MUI. LPPOM have responsibility to validate all of knowledge to be share .To ensure validity of knowledge to be share
\end{abstract}

Keyword: Knowledge Management Systems(KMS), LPPOM MUI, Knowledge Sharing

\section{Background}

Knowledge is a resource of organization that must be spread among all stakeholder. Knowledge management is needed to increase the utilization of knowledge in an organization. By Using knowledge management systems, helps organizations to collect and share knowledge.

Knowledge sharing among the food producers, community and LPPOM MUI are needed because there are many food producer did not certified their product. Because they don't have enough knowledge about how to certified their product. On the other hand consumer need the certainty of halalness of the product they consume 
Therefore, to improve the benefits of knowledge that belong to food producr, community and LPPOM MUI, the management of knowledge must be well done. It's meant the knowledge management governance must implemented at LPPOM MUI.

Research conducted by Suzanne Zyngier, entitled Knowledge Management Governance: "A Multifaceted Approach to Organizational Decision and Innovation Support", present that Knowledge management is a strategy to support enhanced decision making through effective control of organizational knowledge. In their research, they presents a preliminary investigation into the governance of strategies to manage knowledge and the relationship between such strategies and organizational structures. They finds that the federated information transfer model is the 'best fit' with a stakeholder model of governance which ensures accountability and responsibility for tasks meeting the needs of all stakeholders. The governance structure established may predicate the ability of the organization to effectively establish a strategy to manage their knowledge.

Siti Zakiah conducts research to explore how knowledge management can be an effective tracking system in the supply chain of the halal food industry

From the above explanation we can see that KMS is important and must be manage with a good governance.

\section{Literatur Review}

According to Drucker (1998), Knowledge is information that changes something or someone, it happens when the information becomes the basis for action, or when the information enables a person or institution to take different actions or more effective actions (Tobing) .

Knowledge Management (KM) is systemic approaches that help the emergence and flow of information and knowledge to the right people at the right time to create value (Tobing).

Knowledge Management System (KMS) is an integrated mechanism and process in storing, maintaining, organizing business information and work related to the creation of various information into permanent organizational intellectual assets (Tobing).

According to Surendro (2009), information technology governance is an integrated part of corporate management that includes leadership, structure, and organizational processes that ensure that corporate information technology can be used to maintain and expand organizational strategies and objectives.

According to ITSMF (2007), IT governance consists of a complete structural framework, processes, and ways of working. According to ITGI (2012), IT governance provides a structure that connects IT processes, IT resources, and information about company strategies and objectives.

Various models of best practice of IT governance in the world have been widely introduced such as: COSO, COBIT, ITIL, and ISO. Each has its advantages and disadvantages, some models of IT governance from a strategic and other point of view 
COBIT, (Control Objectives for Information and Information related Technologies) is one of the most well-known IT Governance frameworks in the IT Governance practitioner community. COBIT 5 analyzes every complete IS function process and offers a descriptive explanation for managing, organizing and auditing IT in organizations broadly and in detail .

COBIT improves clear rules and good practices for IT control within the organization. COBIT used to improve regulation, helping organizations to increase the value that they want to achieve with IT implementation, enabling to align and simplify the implementation of COBIT

\section{Research Method}

This research is a quantitative research with its application in accordance with the concept of COBIT 5 framework. In this research to collect data are used Interview, Observation, Study of literature and Questionnaire. Questionnaire using likert scale. The method of data Analysis are using PAM that consist : Initiation, Planning the Assessment, Briefing, Data collection, Data validation, Process attribute rating, Reporting the result.

\section{Result and Discussion}

On this section present the result of this study. The are two result namely the results of domain mapping, and the measurement of the domain capability level. The explanation of the result in the following explanation:

\section{A. Domain Mapping}

After Focus Group Disccusion we can chhose the domain to be evaluated before this research conducted. FGD conducted with LPPOM MUI as the object of our research. In the process of choosing a domain (Goal Cascading), the process of identifying the problem to determining the domain is an important step.

The mapping of enterprise goals based on vision, mission and problems in LPPOM MUI in accordance with COBIT 5 is Information-based strategic decision making. Furthermore, we mapping enterprises goals to IT-related goals based on vision, mission and problems in accordance with COBIT 5. Thus, based on the mapping, then the process to be evaluated is BAI08 (Manage Knowledge).

\section{B. Measurement of Capability Level}

After collecting data of questionnaires that have been filled by respondents. Process of data validation are conducted. We calculating the capability level of management knowledge process. The result of capability level of the management knowledge in the Table 1. 
Table. 1. Capability Level

\begin{tabular}{|c|c|c|c|}
\hline No & Sub Process & Capability Value & Capability Level \\
\hline 1 & BAl08.1 & 3.22 & 3 \\
\hline 2 & BAl08.2 & 3.27 & 3 \\
\hline 3 & BAl08.3 & 2.66 & 2 \\
\hline 4 & BAl08.4 & 2.25 & 2 \\
\hline 5 & BAl08.5 & 2.15 & 2 \\
\hline $\begin{array}{c}\text { Rata- } \\
\text { Rata }\end{array}$ & & 2.71 & 2.4 \\
\hline
\end{tabular}

On the table 1, the value for current condition of knowledge management process (BAI08) 2.7 or capability level is at level 2 (Manage Process). It's means that the knowledge management process at the LPPOM MUI is implemented in a managed fashion (planned, monitored and adjusted) and but not all of its work products are appropriately established, controlled and maintained. To improve the capability level LPPOM MUI must be complete all of the work product.

In addition to assessing the level of capability to see the implementation of knowledge management, observations and interviews are also conducted to obtain evidence of the implementation of knowledge management activities. The evidence that find ont

\section{Conclusions}

From the analyzing the information technology governance at LPPOM MUI, it is known that the results of the evaluation of knowledge management process capability value is 2.7 with the level capability is 2 (Manage Knowledge). It's meant that the implementation of knowledge management activities in accordance with COBIT and implemented in a managed fashion (planned, monitored and adjusted) Overall knowledge management activities in the LPPOM MUI is good, because the value and the existing process of knowledge management in accordance with standard of COBIT 5 guide. But there is evidence of knowledge management process that are not all processes are well documented

To improve the knowledge management process at level 2, LPPOM MUI must complete the document for each process. Whereas to improve capability level to level 3, LPPOM MUI must evaluate the success of each knowledge management process.

By improving knowledge management governance, it is expected that KMS owned by LPPOM MUI will benefit as expected 


\section{Refference}

IT Service Management Forum2007), www.itsmfi.org

ITGI. Board Briefing on IT Governance, IT Governance Institute. Retrieved from http://www.itgi.org. 2012.

P. L. Tobing, Knowledge Management Konsep Arsitektur dan Implementasi, Yogyakarta: Graha IImu, 2007.

Suzanne Zyngier. Knowledge Management Governance: A Multifaceted Approach to Organisational Decision and Innovation Support. School of Information Management and Systems Monash University Melbourne, Australia. 2004.

Surendro, K., 2009, Implementasi Tata Kelola Teknologi Informasi, Informatika, Bandung 